\title{
The complete mitochondrial genome of Pallisentis celatus (Acanthocephala) with phylogenetic analysis of acanthocephalans and rotifers
}

\author{
Ting Shuang Pan ${ }^{1,2}$ and Pin Nie $^{3}$ \\ ${ }^{1}$ College of Fisheries, Huazhong Agricultural University, Wuhan, Hubei Province, China; \\ ${ }^{2}$ Fisheries Institute, Anhui Academy of Agricultural Sciences, Hefei, Anhui Province, China; \\ ${ }^{3}$ College of Fisheries, Jimei University, Xiamen, Fujian Province, China
}

\begin{abstract}
Acanthocephalans are a small group of obligate endoparasites. They and rotifers are recently placed in a group called Syndermata. However, phylogenetic relationships within classes of acanthocephalans, and between them and rotifers, have not been well resolved, possibly due to the lack of molecular data suitable for such analysis. In this study, the mitochondrial (mt) genome was sequenced from Pallisentis celatus (Van Cleave, 1928), an acanthocephalan in the class Eoacanthocephala, an intestinal parasite of rice-field eel, Monopterus albus (Zuiew, 1793), in China. The complete mt genome sequence of $P$. celatus is 13855 bp long, containing 36 genes including 12 protein-coding genes, 22 transfer RNAs (tRNAs) and 2 ribosomal RNAs (rRNAs) as reported for other acanthocephalan species. All genes are encoded on the same strand and in the same direction. Phylogenetic analysis indicated that acanthocephalans are closely related with a clade containing bdelloids, which then correlates with the clade containing monogononts. The class Eoacanthocephala, containing P. celatus and Paratenuisentis ambiguus (Van Cleave, 1921) was closely related to the Palaeacanthocephala. It is thus indicated that acanthocephalans may be just clustered among groups of rotifers. However, the resolving of phylogenetic relationship among all classes of acanthocephalans and between them and rotifers may require further sampling and more molecular data.
\end{abstract}

Keywords: Eoacanthocephala, mitochondrion, mt genome, rice-field eel, China, phylogeny, Syndermata

Acanthocephalans, which use vertebrates as definitive hosts and arthropods as intermediate hosts, are a small group of obligate endoparasites with a total of about 1200 species in the world (Schmidt 1985). They were historically classified in the phylum Nematoda (Dougherty 1951), but were more recently recognized as a group within the phylum Rotifera in either traditional morphological (Melone et al. 1998, Sørensen and Giribet 2006) or molecular phylogenetic analyses (García-Varela and Nadler 2006). Acanthocephalans and rotifers are now grouped in the taxon Syndermata (see Ahlrichs 1997). However, the phylogenetic relationship of acanthocephalans with three classes of rotifers, i.e. Bdelloidea, Monogononta and Seisonidea, has not been resolved (Garey et al. 1998, García-Varela and Nadler 2006, Witek et al. 2008, Fontaneto and Jondelius 2011).

However, parasitologists considered acanthocephalans or spiny-headed worms to represent the phylum Acanthocephala, which contains four classes, Archiacanthocephala, Eoacanthocephala, Palaeacanthocephala, and Polyacanthocephala (Amin 1987, Monks 2001). Several authors have attempted to examine the phylogenetic rela- tionship of these classes (Near et al. 1998, García-Varela et al. 2000, Monks 2001, Near 2002, García-Varela and Nadler 2006), but their phylogenetic relationships remain to be resolved (García-Varela and Nadler 2005). Nevertheless, it seems possible that the Eoacanthocephala and Polyacanthocephala are closely related, representing a sister group to the Palaeacanthocephala, with the Archiacanthocephala as a separate clade (García-Varela et al. 2002, García-Varela and Nadler 2006).

These phylogenetic studies have been based on the analysis of one or two genes, such as ribosomal RNA genes (García-Varela et al. 2002, García-Varela and Nadler 2005, 2006, Mark Welch 2005, Passamaneck and Halanych 2006, Sørensen and Giribet 2006), ITS (Král'ová-Hromadová et al. 2003, Perrot-Minnot 2004), or coxl (Perrot-Minnot 2004), which may not be phylogenetically informative as $\mathrm{mt}$ genomes used much more commonly in phylogenetic studies (Stach et al. 2010, Zhao et al. 2010, Fontaneto and Jondelius 2011, Park et al. 2011, Abascal et al. 2012). It is only recently that the $\mathrm{mt}$ genome, which may be much more informative for phylogenetic analysis, has been sequenced in acanthocephalans, 
Table 1. PCR primers used for cloning of the mitochondrial genome of Pallisentis celatus.

\begin{tabular}{|c|c|c|c|}
\hline Primer & DNA sequence $\left(5^{\prime}-3^{\prime}\right)$ & $\begin{array}{l}\text { Estimated size of } \\
\text { PCR products }\end{array}$ & Reference \\
\hline $\operatorname{cox} 1 \mathrm{~F}$ & GGTCAACAAATCATAAAGATATTGG & \multirow{2}{*}{$680 \mathrm{bp}$} & \multirow{2}{*}{ Folmer et al. (1994) } \\
\hline $\operatorname{cox} 1 \mathrm{R}$ & TAAACTTCAGGGTGACCAAAAAATCA & & \\
\hline $\operatorname{cox} 2 \mathrm{~F}$ & GGWCAYCARTGATATTGA & \multirow{2}{*}{$340 \mathrm{bp}$} & \multirow{2}{*}{ This study } \\
\hline $\operatorname{cox} 2 \mathrm{R}$ & CAATKACAATYGGTATAAA & & \\
\hline $\operatorname{rrnLF}$ & GACYGTRCTWAGGTAGCRTRATC & \multirow{2}{*}{$600 \mathrm{bp}$} & \multirow{2}{*}{ Gazi et al. (2012) } \\
\hline $\operatorname{rrnLR}$ & AWRDRATRATCCAACATCGAGGTA & & \\
\hline cobF & CTTTTTTAGGGTATGTTTTACC & \multirow{2}{*}{$600 \mathrm{bp}$} & \multirow{2}{*}{ Gazi et al. (2012) } \\
\hline cobR & TCWACARYAYAWCCTCC & & \\
\hline $\operatorname{cox} 1-16 \mathrm{sF}$ & CTTTGGTGGTTACTGCTTTCTTAG & \multirow{2}{*}{$1.9 \mathrm{~kb}$} & \multirow{2}{*}{ This study } \\
\hline $\operatorname{cox} 1-16 \mathrm{sR}$ & ATCCCCAGAGTAACTACACCCTTG & & \\
\hline $16 \mathrm{~S}-\mathrm{cobF}$ & TTCAAGGGTGTAGTTACTCTGGGG & \multirow{2}{*}{$7.5 \mathrm{~kb}$} & \multirow{2}{*}{ This study } \\
\hline $16 \mathrm{~S}-\mathrm{cobR}$ & GACACCAATGCCTCACCAACTACA & & \\
\hline $\operatorname{cob}-\operatorname{cox} 2 \mathrm{~F}$ & AATCCACTGGGGGTGTTTTCTTCT & \multirow{2}{*}{$2.8 \mathrm{~kb}$} & \multirow{2}{*}{ This study } \\
\hline cob-cox $2 R$ & GTCAAATACACGCCTACCCAAGAA & & \\
\hline $\operatorname{cox} 2-\operatorname{cox} 1 \mathrm{~F}$ & AGGTTTTTGGGGGTAGGGTCAGAT & \multirow{2}{*}{$2.3 \mathrm{~kb}$} & \multirow{2}{*}{ This study } \\
\hline $\operatorname{cox} 2-\operatorname{cox} 1 \mathrm{R}$ & AAACCTCCCATAAAAGCAGGCATT & & \\
\hline
\end{tabular}

namely Leptorhynchoides thecatus (Linton, 1891) of the Palaeacanthocephala, Oncicola luehei (Travassos, 1917) and Macracanthorhynchus hirudinaceus (Pallas, 1781) of the Archiacanthocephala, and Paratenuisentis ambiguus of the Eoacanthocephala (see Steinauer et al. 2005, Gazi et al. 2012, Weber et al. 2013). More mitochondrial genome sequences are apparently needed to resolve the phylogenetic relationship of acanthocephalans at various taxonomical levels, as well as to understand their relationship with other animals.

Pallisentis celatus of the class Eoacanthocephala is an endoparasite in intestines of rice-field eel, Monopterus albus (Zuiew). Its wide distribution in China and in some Southeast Asian countries, such as Vietnam, and its abundant occurrence in the eel provide opportunities for sampling the parasite easily (Amin et al. 2004, Wang et al. 2004). Previous studies on this parasite have been carried out with focus on its morphology, epidemiology and population dynamics, and even infection control (Amin et al. 2004, Wang et al. 2004, Zeng and Wang 2007).

In the present study, the complete mt genome of $P$. celatus obtained from $M$. albus was sequenced. The gene arrangement, nucleotide composition and codon usage were further analyzed, and the phylogenetic relationship of $P$. celatus was examined with the combination of $\mathrm{mt}$ genomes from other acanthocephalans and rotifers in order to assess phylogenetic relationships within the Syndermata.

\section{MATERIALS AND METHODS}

\section{Parasite samples and DNA extraction}

Pallisentis celatus was dissected out under a microscope from intestines of Monopterus albus, which were captured in rice field around Wuhan, Hubei Province of China. Parasite specimens were then washed in $0.6 \%$ sodium chloride, before being kept in $70 \%$ ethanol at $-20{ }^{\circ} \mathrm{C}$ for further use. The total genomic DNA was extracted using the Promega Wizard ${ }^{\circledR}$ Ge- nomic DNA Purification Kit (Promega) according to the manufacturer's protocol.

\section{PCR amplification and sequencing}

Initially, four partial gene fragments of $\operatorname{cox} 1, \operatorname{cox} 2, \operatorname{cob}$ and $r r n L$ were amplified using reported primer sets $(\operatorname{cox} 1 \mathrm{~F} / \operatorname{cox} 1 \mathrm{R}$, cobF/cobR, and rrnLF/rrnLR) (Folmer et al. 1994, Gazi et al. 2012) (Table 1), and primer set ( $\operatorname{cox} 2 \mathrm{~F} / \operatorname{cox} 2 \mathrm{R})$ designed from conserved regions of published sequences of acanthocephalans (Leptorhynchoides thecatus and Oncicola luehei with their GenBank accession numbers listed in Table 2) and two rotifer species (Rotaria rotatoria and Brachionus plicatilis; Table 2). Polymerase chain reaction (PCR) was carried out with the following amplification conditions: $94^{\circ} \mathrm{C}$ for $3 \mathrm{~min} ; 35$ cycles of $94^{\circ} \mathrm{C}$ for $30 \mathrm{~s}, 45^{\circ} \mathrm{C}$ for $30 \mathrm{~s}$ and $72^{\circ} \mathrm{C}$ for $1 \mathrm{~min}$, and incubation at $72^{\circ} \mathrm{C}$ for $10 \mathrm{~min}$.

The amplified PCR products were cloned into $\mathrm{pMD} 18$ - T vector (Takara), and transformed into competent Escherichia coli strain DH5 $\alpha$. The nucleotide sequences obtained from these partial gene fragments were then used to design specific primers for long PCR amplification for cloning the remaining sequence of $\mathrm{mt}$ genome (Table 1). PCRs were carried out with the primers (Table 1) and the LA Taq (Takara) at the following conditions: $94^{\circ} \mathrm{C}$ for $3 \mathrm{~min}$; 33 cycles of $94^{\circ} \mathrm{C}$ for $30 \mathrm{~s}, 60^{\circ} \mathrm{C}$ for $30 \mathrm{~s}$ and $68^{\circ} \mathrm{C}$ for $10 \mathrm{~min}$, and extension at $72^{\circ} \mathrm{C}$ for $10 \mathrm{~min}$. The amplified DNA fragments were approximately 1.9, 7.0, 2.8 and $2.3 \mathrm{~kb}$ long, respectively, which extended from downstream of coxl to upstream of $r r n L$, from downstream of $r r n L$ to upstream of $c o b$, from downstream of $c o b$ to upstream of $\operatorname{cox} 2$, and from downstream of $\operatorname{cox} 2$ to upstream of $\operatorname{cox} 1$.

The amplified long PCR products were gel-isolated and extracted using the Omega Gel Extraction Kit (Omega). After gel purification, each of the long PCR products was ligated into pMD18-T cloning vector (Takara) and then transformed into competent $E$. coli $\mathrm{DH} 5 \alpha$. The recombinant clones were selected and sequenced using a Big Dye Terminators Cycle-Sequencing Kit (ABI) in both directions by the primer walking method. Sequence data were analyzed using the SeqMan program from DNASTAR (http://www.DNASTAR.com/). The complete nucleotide sequence was submitted to the GenBank database with accession number JQ943583. 
Table 2. Species and their mitochondrial genomes used in the phylogenetic analysis. Newly sequenced mt genome in bold.

\begin{tabular}{|c|c|c|}
\hline Species & Taxonomic group & GenBank accession no. \\
\hline \multicolumn{3}{|l|}{ Lophotrochozoa } \\
\hline Mytilus galloprovincialis & Mollusca & NC 006886 \\
\hline Musculista senhousiavoucher & Mollusca & GU001954 \\
\hline Terebellides stroemi & Annelida & EU236701 \\
\hline Lumbricus terrestris & Annelida & NC_001673 \\
\hline Loxosomella aloxiata & Entoprocta & $\mathrm{AB} \overline{2} 64800$ \\
\hline Loxocorone allax & Entoprocta & NC_010431 \\
\hline Urechis caupo & Echiura & AY619711 \\
\hline Urechis unicinctus & Echiura & NC_012768 \\
\hline Sipunculus nudus & Sipunculida & NC_011826 \\
\hline Laqueus rubellus & Brachiopoda & NC_002322 \\
\hline Terebratalia transversa & Brachiopoda & AF331161 \\
\hline Phoronis psammophila & Phoronida & AY368231 \\
\hline Flustra foliacea & Bryozoa & JQ061319 \\
\hline Watersipora subtorquata & Bryozoa & NC_011820 \\
\hline \multicolumn{3}{|l|}{ Platyzoa } \\
\hline Pallisentis celatus & Acanthocephala; Eoacanthocephala & JQ943583 \\
\hline Paratenuisentis ambiguus & Acanthocephala; Eoacanthocephala & FR856885 \\
\hline Leptorhynchoides thecatus & Acanthocephala; Palaeacanthocephala & NC_006892 \\
\hline Oncicola luehei & Acanthocephala; Archiacanthocephala & NC_016754 \\
\hline Macracanthorhynchus hirudinaceus & Acanthocephala; Archiacanthocephala & FR856886 \\
\hline Rotaria rotatoria & Rotifera; Bdelloidea & NC_013568 \\
\hline Philodina citrina & Rotifera; Bdelloidea & FR856884 \\
\hline Adineta vaga & Rotifera; Bdelloidea & 1 \\
\hline Habrotrocha constricta & Rotifera; Bdelloidea & 2 \\
\hline Macrotrachela quadricornifera & Rotifera; Bdelloidea & 3 \\
\hline Adineta ricciae & Rotifera; Bdelloidea & 4 \\
\hline Philodina roseola & Rotifera; Bdelloidea & 5 \\
\hline Brachionus plicatilis & Rotifera; Monogononta & NC_010472 part-I \\
\hline Brachionus calyciflorus & Rotifera; Monogononta & 6 \\
\hline Brachionus manjavacas & Rotifera; Monogononta & 7 \\
\hline Paragonimus westermani & Platyhelminthes & NC_002354 \\
\hline Taenia solium & Platyhelminthes & NC_004022 \\
\hline Taenia crassiceps & Platyhelminthes & NC_002547 \\
\hline Echinococcus multilocularis & Platyhelminthes & NC_000928 \\
\hline \multicolumn{3}{|l|}{ Ecdysozoa } \\
\hline Homarus americanus & Arthropoda & HQ402925 \\
\hline Scutigera coleoptrata & Arthropoda & NC_005870 \\
\hline Opisthopatus cinctipes & Onychophora & NC_014273 \\
\hline Epiperipatus biolleyi & Onychophora & NC_009082 \\
\hline Priapulus caudatus & Priapulida & NC_008557 \\
\hline \multicolumn{3}{|l|}{ Deuterostomia } \\
\hline Branchiostoma floridae & Cephalochordata & NC_000834 \\
\hline Acanthaster planci & Echinodermata & NC_007788 \\
\hline Sarotherodon melanotheron & Chordata & NC_015611 \\
\hline Rhabdopleura compacta & Hemichordata & NC_015649 \\
\hline \multicolumn{3}{|l|}{ Radiata (outgroup) } \\
\hline Montastraea annularis & Cnidaria & NC_007224 \\
\hline
\end{tabular}

Abbreviations: 1 - indicates some fragments of the mt genome, i.e. JX183993, JX184001, JX184009, JX184017, JX184025, JX184033, JX184056, JX184064, JX184072; 2 - indicates some fragments of the mt genome, i.e. JX183994, JX184002, JX184010, JX184018, JX184026, JX184034, JX184057, JX184065, JX184073; 3 - indicates some fragments of the mt genome, i.e. JX183995, JX184003, JX184011, JX184019, JX184027, JX184035, JX184059, JX184067, JX184075; 4 - indicates some fragments of the mt genome, i.e. JW861109, JW861111, JW861112; 5 - indicates some fragments of the mt genome, i.e. JW861079, JW861081, JW868082, JW861084, JW861085; 6 - indicates some fragments of the mt genome, i.e. JX463644, JX463643, JX463645, JX463646, JX433647, JX463648, JX433649, JX463650, JX463651; 7 - indicates some fragments of the mt genome, i.e. JW861101, JW861103, JW861104, JW861106.

\section{Sequence analyses and genome drawing}

Nucleotide composition, amino acid composition and codon usage were initially analyzed using MEGA version 5 (Tamura et al. 2011). Protein-coding genes were analyzed through the Open Reading Frame Finder (http://www.ncbi.nlm.nih.gov/gorf/gorf. html) using invertebrate mt code. Two rRNAs were identified in their similarity to those published $\mathrm{mt}$ genomes of acanthocephalans by BLAST search (http://blast.ncbi.nlm.nih.gov/Blast.cgi). The 5' and 3' ends of the large ribosomal RNA $(r r n L)$ and small ribosomal RNA $(r r n S)$ were assumed to be adjacent to the flank- 
Table 3. Mitochondrial genome organization of Pallisentis celatus.

\begin{tabular}{lccccccc}
\hline Nucleotide & $\begin{array}{c}\text { Length A }(\%) \\
\text { (bp) }\end{array}$ & $\mathrm{C}(\%)$ & $\mathrm{T}(\%)$ & $\mathrm{G}(\%)$ & $\begin{array}{c}\mathrm{A}+\mathrm{T} \\
(\%)\end{array}$ & $\begin{array}{c}\mathrm{G}+\mathrm{C} \\
(\%)\end{array}$ \\
\hline $\begin{array}{l}\text { Entire sequence } \\
\text { Protein coding }\end{array}$ & 13855 & 20.7 & 9.7 & 40.8 & 28.8 & 61.5 & 38.5 \\
$\begin{array}{l}\text { sequence } \\
\text { Codon position* }\end{array}$ & 10041 & 18.4 & 9.4 & 42.8 & 29.4 & 61.2 & 38.8 \\
$\begin{array}{l}\text { 1st } \\
\text { 2nd }\end{array}$ & 3347 & 20.9 & 8.3 & 36.5 & 34.3 & 57.4 & 42.6 \\
3rd & 3347 & 13.2 & 12.7 & 51.8 & 22.3 & 65.0 & 35.0 \\
$\begin{array}{l}\text { Ribosomal RNA } \\
\text { genes sequence }\end{array}$ & 1457 & 28.2 & 10.2 & 35.4 & 26.2 & 63.6 & 36.4 \\
$\begin{array}{l}\text { Transfer RNA } \\
\text { genes sequence }\end{array}$ & 1242 & 23.8 & 10.1 & 38.1 & 28.0 & 61.9 & 38.1 \\
$\begin{array}{l}\text { Non-coding } \\
\text { region 1 }\end{array}$ & 424 & 28.1 & 10.6 & 25.4 & 36.8 & 52.6 & 47.4 \\
$\begin{array}{l}\text { Non-coding } \\
\text { region 2 }\end{array}$ & 317 & 29.0 & 11.7 & 37.5 & 21.8 & 66.6 & 33.4 \\
\hline
\end{tabular}

*Termination codons were excluded.

ing genes. The 22 tRNAs were identified using the tRNAscanSE program (Lowe and Eddy 1997), DOGMA (Wyman et al. 2004) or manually through comparing specific anticodon sequences and secondary structures with those found in $L$. thecatus and $O$. luehei, when tRNA genes were not recognized by these two programs. The circular mt genome map of $P$. celatus was drawn by using GenomeVx (Conant and Wolfe 2008).

\section{Phylogenetic analysis}

In order to include as many rotifer species as possible, phylogenetic analysis was performed using 9 of the 12 protein-coding genes, as nad2, nad 3 and nad6 were absent from sequence data of some species of rotifers (Lasek-Nesselquist 2012). The metazoan groups represented in the analysis included 14 lophotrochozoans, 19 platyzoans with $P$. celatus and other four acanthocephalans, 5 ecdysozoans and 4 deuterostomes. The mt genome sequence data from one cnidarian, Montastraea annularis (Ellis et Solander, 1786), was included in the analysis as outgroup. A list of species and GenBank accession numbers of their mt genomes are given in Table 2. Nine concatenated protein-coding genes of $P$. celatus were translated into amino acids using invertebrate $\mathrm{mt}$ genetic code and then aligned using ClustalX with default options (Thompson et al. 1997). The most conserved sequence regions (1125 amino acid) were selected for phylogenetic analysis from 9 concatenated genes using Gblocks program with default options (Castresana 2000).

Phylogenetic analysis of conserved amino acid sequences was performed using Bayesian Inference (BI) by MrBayes version 3.2 (Huelsenbeck and Ronquist 2001). For BI analysis, the best fit model was estimated by using Akaike Information Criterion (AIC) and ProTest version 2.0 (Abascal et al. 2005). ProTest selected MtArt with a gamma distribution $(+\mathrm{G})$, a portion of invariable sites $(+\mathrm{I})$, and empirical base frequencies $(+\mathrm{F})$ as the bestfit model for amino acid substitution, followed by MtArt $+\mathrm{G}+\mathrm{F}$, MtArt $+\mathrm{I}+\mathrm{G}$, MtArt $+\mathrm{G}$, and RtREV $+\mathrm{I}+\mathrm{G}+\mathrm{F}$. Since none of the MtArt model is implemented in MrBayes, RtREV as the next best available model was used for the matrix (again applying options $+\mathrm{I},+\mathrm{G}$ and $+\mathrm{F}$ ). Bayesian analysis was run for 1000000 generations and sampled every 100 generations with four Markov Chain Monte Carlo (MCMC) chains. Bayesian posterior probability (BPP) values were determined after discarding the initial 2000 saved trees (the first $2 \times 10^{5}$ generations) as burn-in.

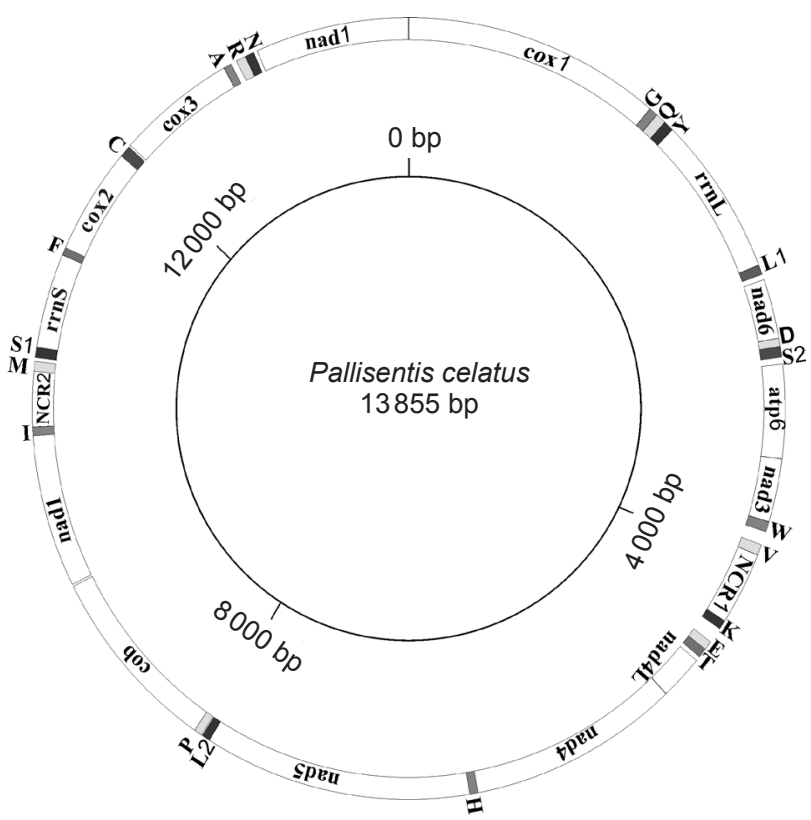

Fig. 1. Circular presentation of the complete mitochondrial genome of Pallisentis celatus. All genes are encoded in the same direction and 22 tRNA genes are designated by a single-letter abbreviation. The two leucine and serine tRNA genes are labeled, according to their anticodon sequences, as L1 (trnL-uag), L2 (trnL-uaa), S1 (trnS-ucu ) and S2 (trnS-uga ), respectively.

\section{RESULTS}

\section{Genes and organization of the mitochondrial genome}

The complete mt genome of Pallisentis celatus is a circular, double-stranded DNA molecule, with a total length of $13855 \mathrm{bp}$. The nucleotide composition of the entire genome sequence is $40.8 \%$ for $\mathrm{T}, 28.8 \% \mathrm{G}, 20.7 \% \mathrm{~A}$ and $9.7 \% \mathrm{C}$ (Table 3 ). The genome contains 36 genes including 12 protein-coding genes, 22 tRNAs and 2 rRNAs ( $r r n L$ and $r r n S$ ). All genes are encoded on the same strand (Fig. 1). A list of gene order, gene length, and intergenic spacer regions is given in Table 4.

\section{Codon usage and sequence features of protein-coding genes}

The entire mt genome of $P$. celatus excessively favours AT. The overall AT composition of protein-coding genes in the genome is $61.2 \%$, which is a little more than that of Oncicola luehei $(58.8 \%)$, and less than that of Leptorhynchoides thecatus (71.6\%), Paratenuisentis ambiguus (67.1\%) and Macracanthorhynchus hirudinaceus $(63.9 \%)$. The codon usage of $P$. celatus protein-coding genes is shown in Table 5.

The protein-coding genes of $P$. celatus $\mathrm{mt}$ genome are composed of T-rich codons. The total length of 12 protein-coding genes in the genome is $10041 \mathrm{bp}$, which consist of 3347 codons, excluding termination codons. Analysis of the codon usage of 12 protein-coding genes revealed that three codons are used frequently, with TTT 
Table 4. Nucleotide composition of the mitochondrial genome of Pallisentis celatus.

\begin{tabular}{|c|c|c|c|c|c|c|c|}
\hline \multirow[t]{2}{*}{ Gene } & \multicolumn{2}{|c|}{ Position } & \multicolumn{2}{|l|}{ Size } & \multicolumn{2}{|l|}{ Codons } & \multirow{2}{*}{$\begin{array}{l}\text { Intergenic } \\
\text { sequence }\end{array}$} \\
\hline & Start & Finish & $\begin{array}{l}\text { No. } \\
\text { of nt }\end{array}$ & $\begin{array}{l}\text { No. } \\
\text { of aa }\end{array}$ & Initiation & $\begin{array}{l}\text { Termi- } \\
\text { nation }\end{array}$ & \\
\hline $\operatorname{cox} 1$ & 1 & 1534 & 1534 & $511 *$ & GTG & $\mathrm{T}$ & 0 \\
\hline $\operatorname{trn} G$ & 1535 & 1587 & 53 & & & & 0 \\
\hline $\operatorname{trn} Q$ & 1589 & 1650 & 62 & & & & 1 \\
\hline $\operatorname{trn} Y$ & 1651 & 1711 & 61 & & & & 0 \\
\hline$r r n L$ & 1712 & 2634 & 923 & & & & 0 \\
\hline $\operatorname{trnL} 1$ & 2635 & 2690 & 56 & & & & 0 \\
\hline nad6 & 2722 & 3063 & 342 & $114 *$ & ATG TAA & TAA & 31 \\
\hline $\operatorname{trn} D$ & 3064 & 3112 & 49 & & & & 0 \\
\hline $\operatorname{trn} S 2$ & 3110 & 3172 & 63 & & & & -3 \\
\hline atp6 & 3211 & 3748 & 538 & $179 *$ & ATG & $\mathrm{T}$ & 38 \\
\hline nad3 & 3749 & 4111 & 363 & $121 *$ & ATA & TAG & 0 \\
\hline $\operatorname{trn} W$ & 4112 & 4171 & 60 & & & & 0 \\
\hline $\operatorname{trn} V$ & 4249 & 4310 & 62 & & & & 77 \\
\hline NCR1 & 4311 & 4731 & 421 & & & & 0 \\
\hline $\operatorname{trn} K$ & 4732 & 4783 & 52 & & & & 0 \\
\hline $\operatorname{trn} E$ & 4874 & 4926 & 53 & & & & -10 \\
\hline $\operatorname{trn} T$ & 4926 & 4981 & 56 & & & & -1 \\
\hline $\operatorname{nad} 4 L$ & 5008 & 5266 & 259 & $86^{*}$ & ATT & $\mathrm{T}$ & 26 \\
\hline nad4 & 5268 & 6519 & 1252 & $417 *$ & ATG & $\mathrm{T}$ & 1 \\
\hline $\operatorname{trn} H$ & 6518 & 6568 & 51 & & & & -2 \\
\hline nad5 & 6568 & 8157 & 1590 & $530 *$ & GTG & TAG & -1 \\
\hline $\operatorname{trnL2}$ & 8158 & 8207 & 50 & & & & 0 \\
\hline $\operatorname{trn} P$ & 8208 & 8262 & 55 & & & & 0 \\
\hline$c o b$ & 8261 & 9349 & 1089 & $363 *$ & ATG & TAG & -2 \\
\hline nad1 & 9362 & 10238 & 877 & $292 *$ & GTG & $\mathrm{T}$ & 12 \\
\hline trnI & 10238 & 10287 & 50 & & & & -1 \\
\hline NCR2 & 10288 & 10602 & 317 & & & & 0 \\
\hline $\operatorname{trn} M$ & 10603 & 10659 & 57 & & & & -2 \\
\hline trnS1 & 10681 & 10739 & 59 & & & & 21 \\
\hline$r r n S$ & 10740 & 11273 & 534 & & & & 0 \\
\hline $\operatorname{trn} F$ & 11274 & 11328 & 55 & & & & 0 \\
\hline $\operatorname{cox} 2$ & 11327 & 11941 & 615 & $205^{*}$ & GTG & TAG & -2 \\
\hline $\operatorname{trn} C$ & 11941 & 12009 & 69 & & & & -1 \\
\hline $\operatorname{cox} 3$ & 12021 & 12714 & 694 & $231 *$ & GTG & $\mathrm{T}$ & 11 \\
\hline $\operatorname{trn} A$ & 12721 & 12777 & 57 & & & & 6 \\
\hline $\operatorname{trn} R$ & 12808 & 12865 & 58 & & & & 30 \\
\hline $\operatorname{trn} N$ & 12865 & 12919 & 55 & & & & -1 \\
\hline nad2 & 12942 & 13853 & 912 & $304 *$ & TTG & TAA & 22 \\
\hline
\end{tabular}

codon used most frequently (8.98\%), followed by TTG $(7.40 \%)$ and GTT $(6.92 \%)$, whereas CGC, TGC, GCC and CCG codons are used only at $0.06 \%, 0.24 \%, 0.27 \%$, and $0.27 \%$, respectively (Table 5). The most frequently encoded amino acids include leucin (Leu - 16.24\%), valim (Val-15.84\%) and glycin (Gly - 10.82\%), accounting for $42.90 \%$ of total amino acid components (Fig. 2).

Four protein-coding genes, nad6, atp6, nad4, cob, start with ATG. Five other protein-coding genes, cox1, nad5, nad1, cox2, cox3, start with GTG, and nad3 starts with ATA, and nad $4 L$ with ATT, and nad 2 with TTG. Six genes use complete stop codons, including four genes with TAG (nad3, nad5, cob and cox2) and two with TAA (nad6 and nad2), whereas other six genes appear to end in incomplete stop codons with T (cox1, cox3, atp6, nad4, nad4L and $n a d 1$ ). Details of initiation and termination codons of 12 protein-coding genes are shown in Table 4.
Table 5. Genetic code and codon usage for the 12 mitochondrial protein-coding genes of Pallisentis celatus.

\begin{tabular}{cccccccc}
\hline Codon & aa & N. & $\%$ & Codon & aa & N & $\%$ \\
\hline TTT & Phe & 301 & 8.98 & TAT & Tyr & 93 & 2.77 \\
TTC & Phe & 36 & 1.07 & TAC & Tyr & 21 & 0.63 \\
TTA & Leu & 203 & 6.05 & TAA & $*$ & 2 & 0.06 \\
TTG & Leu & 248 & 7.40 & TAG & $*$ & 4 & 0.12 \\
CTT & Leu & 46 & 1.37 & CAT & His & 28 & 0.84 \\
CTC & Leu & 11 & 0.33 & CAC & His & 10 & 0.30 \\
CTA & Leu & 16 & 0.48 & CAA & Gln & 16 & 0.48 \\
CTG & Leu & 19 & 0.57 & CAG & Gln & 19 & 0.57 \\
ATT & Ile & 121 & 3.61 & AAT & Asn & 33 & 0.98 \\
ATC & Ile & 23 & 0.69 & AAC & Asn & 12 & 0.36 \\
ATA & Met & 68 & 2.03 & AAA & Lys & 32 & 0.95 \\
ATG & Met & 110 & 3.28 & AAG & Lys & 33 & 0.98 \\
GTT & Val & 232 & 6.92 & GAT & Asp & 54 & 1.61 \\
GTC & Val & 21 & 0.63 & GAC & Asp & 8 & 0.24 \\
GTA & Val & 79 & 2.36 & GAA & Glu & 35 & 1.04 \\
GTG & Val & 198 & 5.91 & GAG & Glu & 49 & 1.46 \\
TCT & Ser & 84 & 2.51 & TGT & Cys & 33 & 0.98 \\
TCC & Ser & 22 & 0.66 & TGC & Cys & 8 & 0.24 \\
TCA & Ser & 38 & 1.13 & TGA & Trp & 38 & 1.13 \\
TCG & Ser & 22 & 0.66 & TGG & Trp & 71 & 2.12 \\
CCT & Pro & 24 & 0.72 & CGT & Arg & 21 & 0.63 \\
CCC & Pro & 11 & 0.33 & CGC & Arg & 2 & 0.06 \\
CCA & Pro & 23 & 0.69 & CGA & Arg & 13 & 0.39 \\
CCG & Pro & 9 & 0.27 & CGG & Arg & 11 & 0.33 \\
ACT & Thr & 23 & 0.69 & AGT & Ser & 57 & 1.70 \\
ACC & Thr & 10 & 0.30 & AGC & Ser & 16 & 0.48 \\
ACA & Thr & 30 & 0.89 & AGA & Ser & 41 & 1.22 \\
ACG & Thr & 17 & 0.51 & AGG & Ser & 75 & 2.24 \\
GCT & Ala & 51 & 1.52 & GGT & Gly & 144 & 4.29 \\
GCC & Ala & 9 & 0.27 & GGC & Gly & 24 & 0.72 \\
GCA & Ala & 31 & 0.92 & GGA & Gly & 45 & 1.34 \\
GCG & Ala & 20 & 0.60 & GGG & Gly & 149 & 4.44 \\
\hline (termintion) codon; & an 9 ano acid & N - number & copies \\
& & & & & & &
\end{tabular}

\section{Transfer RNA and rRNA genes}

Twenty-two tRNAs encoded in the mt genome of $P$. celatus are identified on the basis of their respective anticodons and secondary structures (Fig. 3); they vary in length from $49(\operatorname{trn} D)$ to $69(\operatorname{trn} C)$ nucleotides, with the inclusion of two trnL and two trnS. The trnR, trnC, trnF, and the two trnS have dihydrouridine (DHU) arm and pseudouridine (TWC) arm. The trnA, trnN, trnE, trnT, trn $Y$ and $\operatorname{trn} V$ lack a DHU arm, and the remaining 12 tRNAs

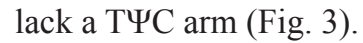

The two rRNAs, rrnL and rrnS, of $P$. celatus mt genome were identified by sequence comparison with those of L. thecatus, O. luehei, Paratenuisentis ambiguus, and $M$. hirudinaceus, and the entire flanking regions between the gene boundaries of their respective adjoining genes were designated as $r r n L$ and $r r n S$. The length of the $r r n L$ and $r r n S$ genes are 923 and $534 \mathrm{bp}$, respectively, and the AT contents are $62.8 \%$ and $64.8 \%$, respectively. The $r r n L$ lies between $\operatorname{trnL} 1$ and $\operatorname{trn} Y$, a same position as observed in $\mathrm{mt}$ genomes of L. thecatus, $O$. luehei and P. ambiguus, but different from the genome in M. hirudinaceus, in which lies between $\operatorname{trn} Y$ and $\operatorname{trnL2}$, whereas the $r r n S$ is situated between trnS1 and trnF, same as in L. theca- 


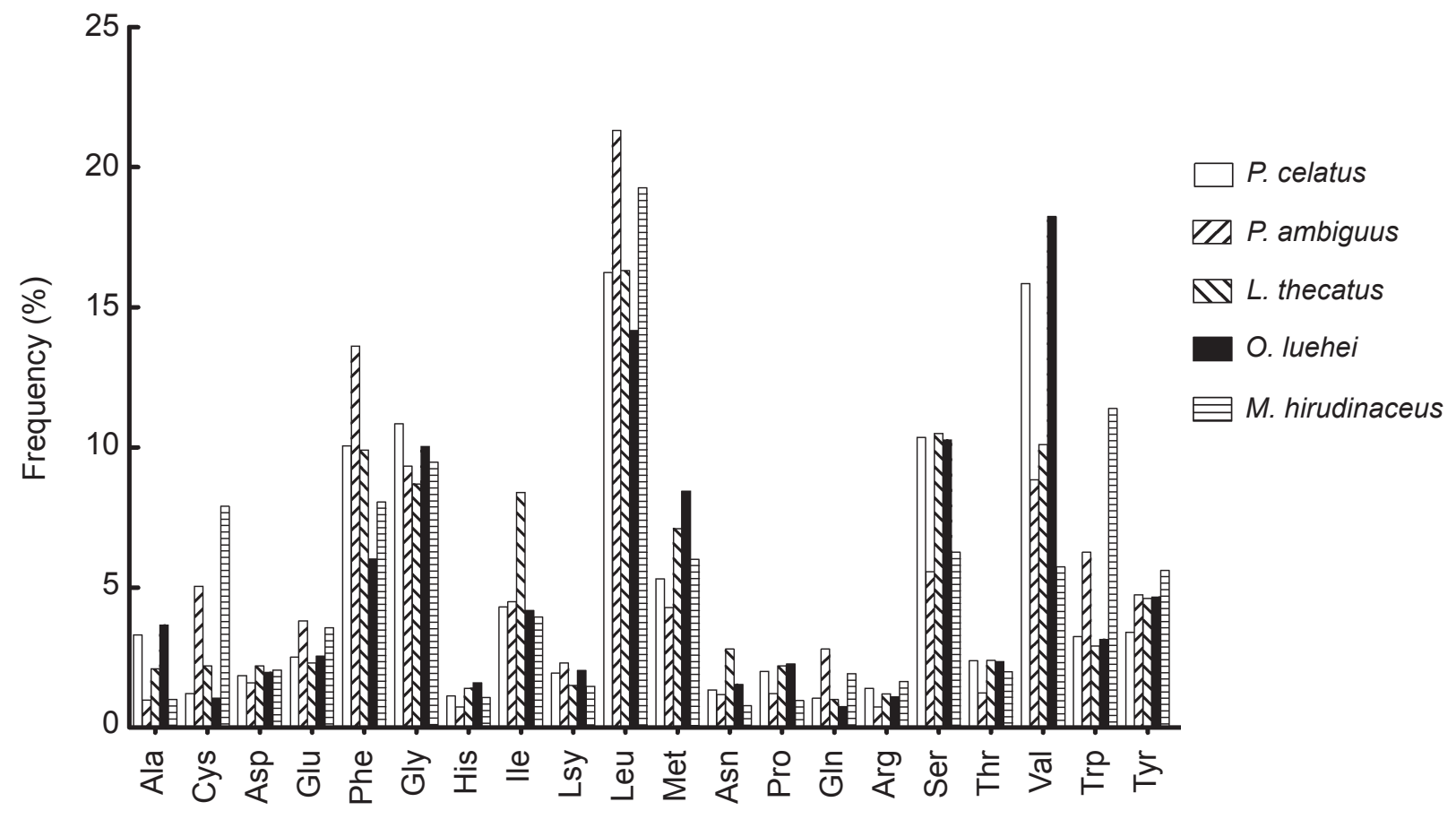

Amino acid

Fig. 2. Comparison in amino acid composition of 12 protein-coding genes in mitochondrial genomes of five acanthocephalan species, Pallisentis celatus, Paratenuisentis ambiguus, Macracanthorhynchus hirudinaceus, Oncicola luehei and Leptorhynchoides thecatus.

tus, but different in $O$. luehei, $P$. ambiguus and $M$. hirudinaceus, in which it lies between trnM and $\operatorname{trnF}$ (Fig. 4).

\section{Non-coding region}

The total length of the non-coding region (NCR) for $P$. celatus is $1104 \mathrm{bp}$, which is composed of 16 intergenic spacer sequences, ranging from 1 to $421 \mathrm{bp}$. Among these, two regions (NCR1 and NCR2) are most prominent in their length. The NCR1 located between $\operatorname{trn} V$ and $\operatorname{trnK}$ is $421 \mathrm{bp}$ long, whereas NCR2 between trnI and trnM is 315 bp long. The A + T contents of NCR1 and NCR2 for the $P$. celatus $\mathrm{mt}$ genome are $52.6 \%$ and $66.6 \%$, respectively (Table 3 ).

\section{Phylogenetic analysis}

Phylogenetic analysis was performed with complete mt genomes of 43 metazoan species (Fig. 5), with cnidarian Montastraea annularis as the outgroup. Five species of acanthocephalans form a clade with high nodal support (1.00 BPP in BI analysis, Fig. 5), among which Pallisentis celatus and Paratenuisentis ambiguus form a clade of Eoacanthocephala (1.00 BPP), which then correlates with L. thecatus (1.00 BPP). Macracanthorhynchus hirudinaceus and $O$. luehei form a separate clade within the acanthocephalan clade. Seven species of Bdelloidea are clustered together with a high support value (1.00 BPP), and three species of Monogononta clustered together with a high support (1.00 BPP). The clade of acanthocephalans is more closely related with the clade containing species in the Bdelloidea, and then with species in the Monogononta. It is shown that acanthocephalans together with Bdelloidea and Monogononta form a clade of Syndermata (Fig. 5).

\section{DISCUSSION}

The mt genome of Pallisentis celatus, an acanthocephalan of the class Eoacanthocephala, was sequenced in the present study, which represents the second $\mathrm{mt}$ genome of a species from the same class and one of the five mt genomes for acanthocephalans. The genome shows characters common for other mt genomes in acanthocephalans, particularly in gene content and gene order of protein-coding genes. The genome of P. celatus, as well as those of other species of acanthocephalans, Paratenuisentis ambiguus, Leptorhynchoides thecatus, Macracanthorhynchus hirudinaceus and Oncicola luehei, are encoded on the same strand and in the same direction, although most metazoan species are encoded on two strands and in two directions (Gissi et al. 2008), and they all contain a total of 36 genes and 12 protein-coding genes, including 22 transfer RNAs (tRNAs) and 2 ribosomal RNAs (rRNAs). The complete mt genome in P. celatus (13855 bp) falls into the range of genome sizes in acanthocephalans (ranging between 13574 and $14281 \mathrm{bp}$ ) and its overall $\mathrm{A}+\mathrm{T}$ content $(61.5 \%)$ is also comparable with those in other acanthocephalans, ranging from $60.2 \%$ in O. luehei to $71.46 \%$ in L. thecatus (Steinauer et al. 2005, Gazi et al. 2012, Weber et al. 2013). 


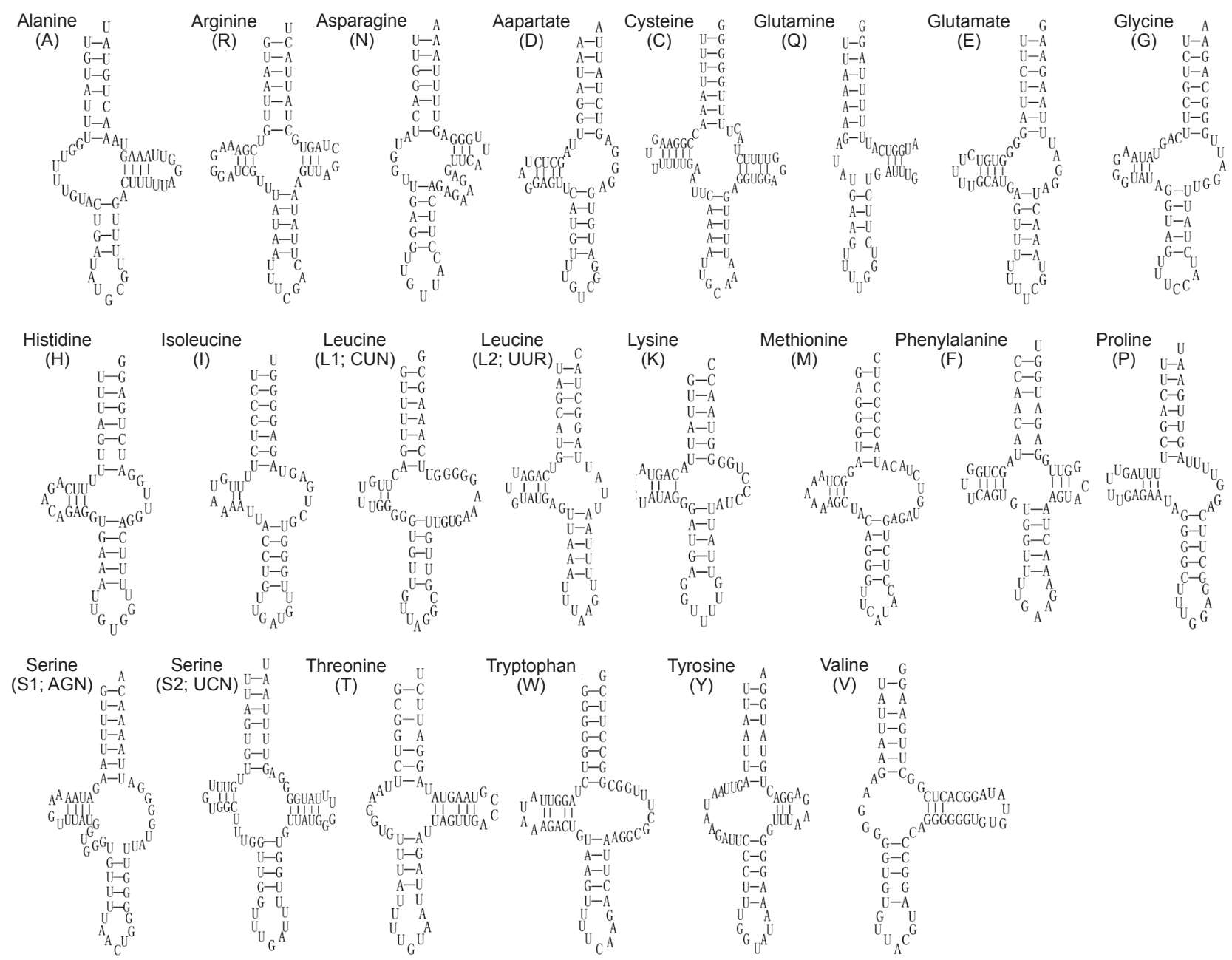

Fig. 3. The predicted secondary structure of 22 tRNAs in mitochondrial genome of Pallisentis celatus.

The 12 protein-coding genes in the $\mathrm{mt}$ genome of $P$. celatus share features in start and stop codons with those in other acanthocephalans. The start codon, ATG, is observed for nad6, atp6, nad4 and cob, GTG observed for cox1, nad5, nad1, cox2 and cox3, and ATA, ATT and TTG for $n a d 3$, nad $4 L$ and $n a d 2$, respectively. Six genes use complete stop codons, including four genes with TAG (nad3, nad5, cob and cox2) and two genes with TAA (nad6 and nad2), whereas other six genes appear to end in incomplete stop codons with T ( $\operatorname{cox} 1, \operatorname{cox} 3$, atp6, nad4, nad $4 \mathrm{~L}$ and $n a d 1$ ). The incomplete stop codon (T) has also been found in cox1, nad1, nad4, nad5 and cob genes for L. thecatus (Steinauer et al. 2005), and T for coxl, cox3 and nad5, and TA for nad6 and cob for O. luehei (Gazi et al. 2012).

Moreover, the character of T-rich codons in proteincoding genes of the $P$. celatus mt genome is also observed in some mt genomes of other invertebrates (Kurabayashi and Ueshima 2000, Lessinger et al. 2000, Steinauer et al. 2005, Gazi et al. 2012). As observed in Pallisentis celatus, mt genomes in other acanthocephalans, i.e. L. thecatus, M. hirudinaceus and P. ambiguus, also contain leucin as the most abundant amino acid in mt genomes of acanthocephalans, being $16.38 \%, 19.27 \%, 21.31 \%$, respectively, with the exception in $O$. luehei which has valin (18.24\%) being the most abundant amino acid and leucin (14.17\%) the second most abundant (Fig. 2). However, it would be interesting to analyze if this is a character typical of $\mathrm{mt}$ genomes of other acanthocephalans.

Comparison in $\mathrm{mt}$ gene orders has often been used as a tool for assessing phylogenetic affinity in metazoans, as gene order may show degree of conservation (Boore and Brown 2000, Lavrov and Lang 2005, Park et al. 2011). However, gene rearrangement was discovered also in acanthocephalans, as found in some other metazoans (Vallès and Boore 2006, Tang and Hyman 2007, Stach et al. 2010). The gene arrangement shows a certain degree of variation in the five $\mathrm{mt}$ genomes of acanthocephalans, despite the conserved location of 12 protein-coding genes and the rrnL and rrnS genes. It seems much more likely that $\operatorname{trn} K$ and $\operatorname{trn} V$ may have a reciprocal position and same is likely true for trnS1 and trnM. trnS2, trnL1 and trnL2 may differ in their positions in the genome for different species of acanthocephalans. Nevertheless, the 


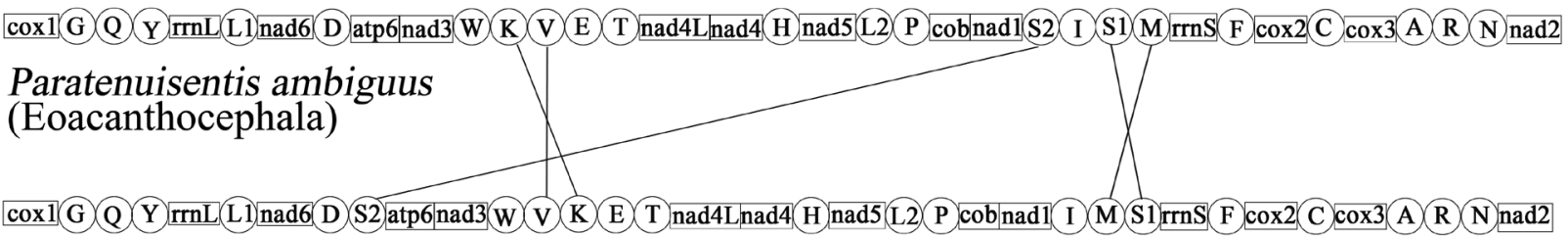

\author{
Pallisentis celatus \\ (Eoacanthocephala)
}

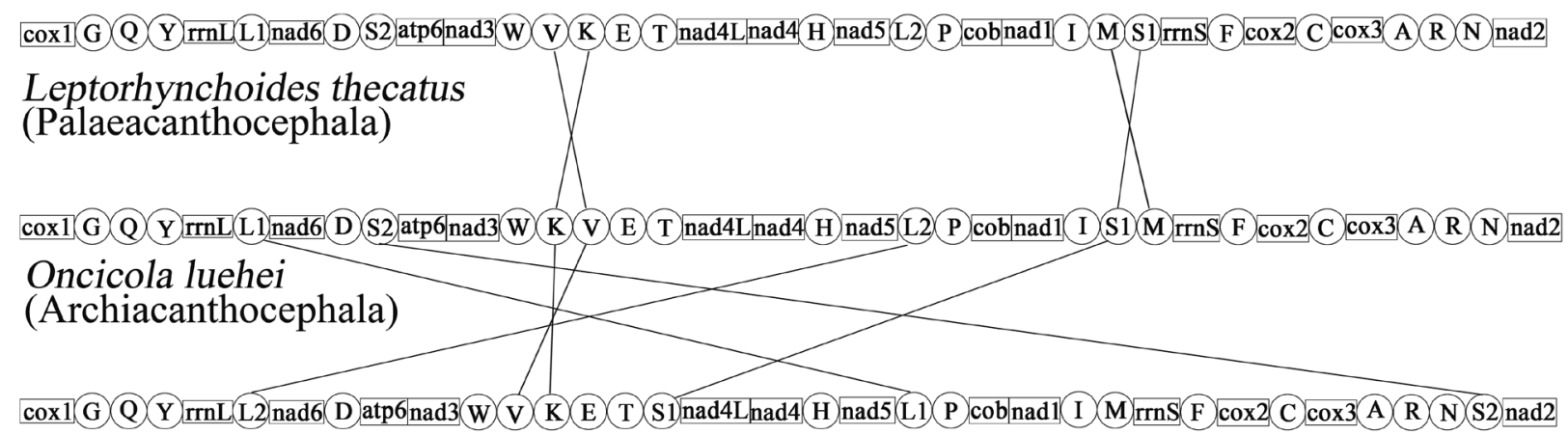

\title{
Macracanthorhynchus hirudinaceus (Archiacanthocephala)
}

Fig. 4. Linearized comparison in the arrangement of mitochondrial genes in five acanthocephalan species, Pallisentis celatus, Paratenuisentis ambiguus, Macracanthorhynchus hirudinaceus, Oncicola luehei and Leptorhynchoides thecatus. Gene and genome size are not shown in scale. All genes are transcribed in the same direction (from left to right). The tRNAs are labeled by singleletter abbreviations.

gene order in the mt genome of $P$. celatus is exactly the same as in that of L. thecatus (Fig. 4). It is thus indicated that $\mathrm{mt}$ genomes in acanthocephalans show certain degree of conservation at least in the gene content and gene order.

Importantly, with the release of $\mathrm{mt}$ genome information from a few species of rotifers (Suga et al. 2008, Min and Park 2009, Lasek-Nesselquist 2012, Weber et al. 2013), it becomes possible to analyze the relationship between acanthocephalans and rotifers. Due to the unavailability of some genes in the mt genome of rotifers (Lasek-Nesselquist 2012), 9 protein-coding genes were used in the present phylogenetic analysis. It appears certain that acanthocephalans are closely related with bdelloids and that they together form a clade with high support value, which then correlates with another group, monogononts in rotifers. This relationship has been supported by analyses using other molecular markers, such as 16S rRNA, 18S rRNA and 28S rRNA (Garey et al. 1998, García-Varela and Nadler 2006, Witek et al. 2008), and using $\mathrm{mt}$ genes and/or genomes (Steinauer et al. 2005, Min and Park 2009, Fontaneto and Jondelius 2011, Gazi et al. 2012, Weber et al. 2013). Using also mt genomes, Podsiadlowski et al. (2009) included only one species of acanthocephalan (listed as the genus Leptorhynchoides) and a monogonont (Brachionus) in the phylogenetic analysis of lophotrochozoans, but phylogenetic relationship in the Syndermata was not even dealt with in their research.
With protein-coding genes, the clade containing acanthocephalans and bdelloids is well revealed with high supporting value in the phylogenetic tree, and it can then be concluded, at least tentatively, that acanthocephalans are closely related to bdelloids and are clustered phylogenetically among rotifers. As three taxa, Bdelloidea, Monogononta and Seisonidea, are reported in the Rotifera (Ahlrichs 1997, Melone et al. 1998), more rotifer samples, especially those in the Seisonidea, which contains only three species (Sørensen et al. 2005), should be included in further phylogenetic research on the Syndermata in order to resolve the phylogeny of these taxa.

It is clearly indicated that the classes Eoacanthocephala and Palaeacanthocephala are closely related, forming a clade, with the Archiacanthocephala as a sister group. This phylogenetic relationship is supported by other studies, with mt genome as molecular marker (Gazi et al. 2012, Weber et al. 2013). Other studies also confirmed that the Palaeacanthocephala and Eoacanthocephala form a sister group. Using 18S rRNA, Near et al. (1998) found that the Palaeacanthocephala and Eoacanthocephala are sister taxa. Morphological phylogeny also supported such relationship (Monks 2001). However, other authors (GarcíaVarela et al. 2002, García-Varela and Nadler 2006), using SSU and LSU rDNA and cox 1 sequences, found that the Polyacanthocephala are closely related with the Eoacanthocephala. As mt genome information on any species of the Polyacanthocephala is absent, phylogenetic relation- 


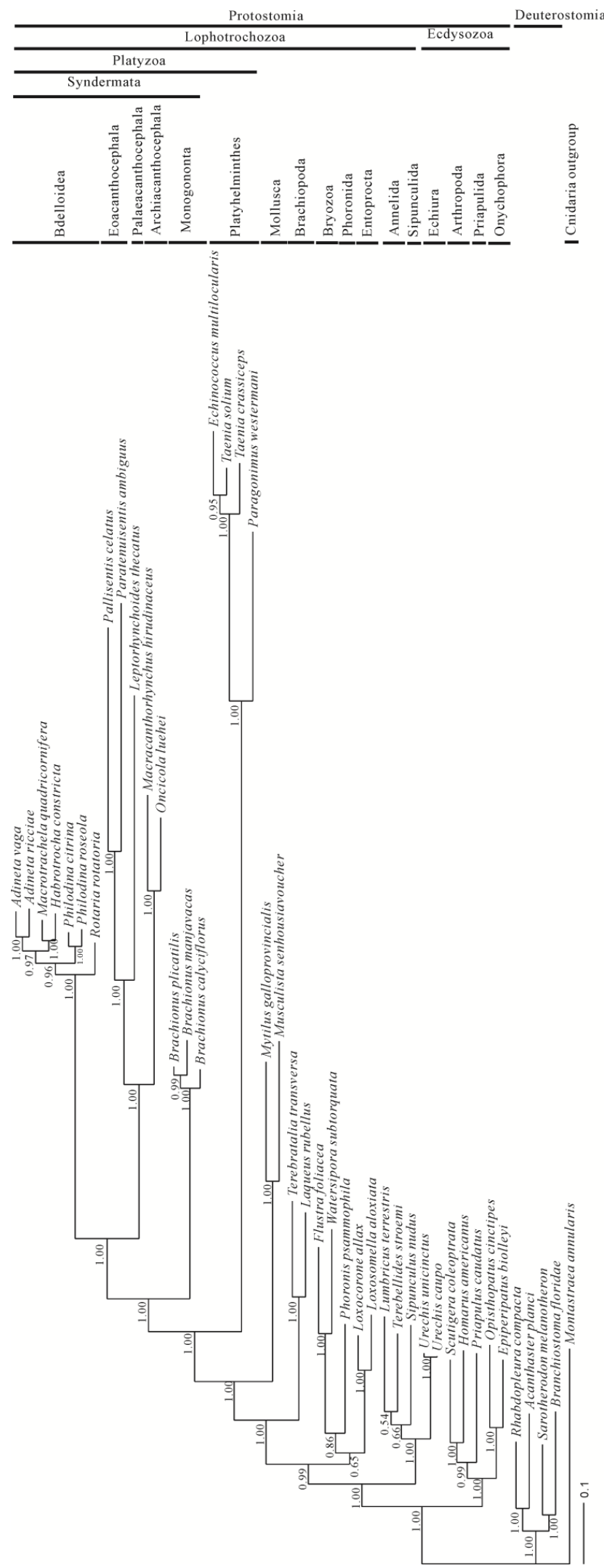

Fig. 5. Bayesian phylogenetic tree inferred from amino acid sequence dataset of 9 protein-coding genes for 43 metazoan mitochondrial genomes. The tree shows the topology based on concatenated data of nine mitochondrial encoded protein sequences (coxl, atp6, nad4L, nad4, nad5, cob, nad1, cox2, cox3). Reconstruction was performed by MrBayes version 3.2 with the protein model of RtRev. The numerical values near internal nodes represent Bayesian posterior probability (BPP) values. 
ship among the classes of acanthocephalans awaits to be further resolved.

In addition, the monophyly of Ecdysozoa was supported (1.00 BPP), which is a sister clade to Lophotrochozoa with high supporting value (1.00 BPP), as reported by other authors (Dunn et al. 2008, Min and Park 2009). However, further phylogenetic research should include more taxa in order to resolve phylogenetic relationship among acanthocephalans and rotifers and in-between.

Acknowledgments. This research was carried out when PN received a Minjiang Fellowship from Fujian Province and with financial support partially from a project (No. 2009CB118703) from the National Basic Research Program (973 Program) of China.

\section{REFERENCES}

Abascal F., Posada D., Zardoya R. 2012: The evolution of the mitochondrial genetic code in arthropods revisited. Mitochondrial DNA 23: 84-91.

Abascal F., Zardoya R., Posada D. 2005: ProtTest: selection of best-fit models of protein evolution. Bioinformatics 21: 21042105.

AhlRichs W.H. 1997: Epidermal ultrastructure of Seison nebaliae and Seison annulatus, and a comparison of epidermal structures within the Gnathifera. Zoomorphology 117: 41-48.

Amin O.M. 1987: Key to the families and subfamilies of Acanthocephala, with the erection of a new class (Polyacanthocephala) and a new order (Polyacanthorhynchida). J. Parasitol. 73: 1216-1219.

Amin O.M., Heckmann R.A., Van Ha N. 2004: On the immature stages of Pallisentis (Pallisentis) celatus (Acanthocephala: Quadrigyridae) from occasional fish hosts in Vietnam. Raffles Bull. Zool. 52: 593-598.

Boore J.L., Brown W.M. 2000: Mitochondrial genomes of Galathealinum, Helobdella, and Platynereis: sequence and gene arrangement comparisons indicate the Pogonophora is not a phylum and Annelida and Arthropoda are not sister taxa. Mol. Biol. Evol. 17: 87-106.

Castresana J. 2000: Selection of conserved blocks from multiple alignments for their use in phylogenetic analysis. Mol. Biol. Evol. 17: 540-552.

Conant G.C., Wolfe K.H. 2008: GenomeVx: simple web-based creation of editable circular chromosome maps. Bioinformatics 24: 861-862.

Dougherty E.C. 1951: Evolution of zoöparasitic groups in the phylum Nematoda, with special reference to host-distribution. J. Parasitol. 37: 353-378.

Dunn C.W., Hejnol A., Matus D.Q., Pang K., Browne W.E., Smith S.A., Seaver E., Rouse G.W., Obst M., Edgecombe G.D., Sørensen M.V., Haddock S.H.D., Schmidt-Rhaesa A., Okusu A., Kristensen R.M., Wheeler W.C., MartinDAle M.Q., Giribet G. 2008: Broad phylogenomic sampling improves resolution of the animal tree of life. Nature 452: 745-749.

Folmer O., Black M., Hoen W., Lutz R., Vrijenhoek R. 1994: DNA primers for amplification of mitochondrial cytochrome c oxidase subunit I from diverse metazoan invertebrates. Mol. Mar. Biol. Biotechnol. 3: 294-299.

Fontaneto D., Jondelius U. 2011: Broad taxonomic sampling of mitochondrial cytochrome c oxidase subunit I does not solve the relationships between Rotifera and Acanthocephala. Zool. Anz. 250: 80-85.

García-Varela M., Cummings M.P., Pérez-Ponce de León G., Gardner S.L., Laclette J.P. 2002: Phylogenetic analysis based on $18 \mathrm{~S}$ ribosomal RNA gene sequences supports the existence of class Polyacanthocephala (Acanthocephala). Mol. Phylogenet. Evol. 23: 288-292.
García-Varela M., Nadler S.A. 2005: Phylogenetic relationships of Palaeacanthocephala (Acanthocephala) inferred from SSU and LSU rDNA gene sequences. J. Parasitol. 91: 14011409.

García-Varela M., Nadler S.A. 2006: Phylogenetic relationships among Syndermata inferred from nuclear and mitochondrial gene sequences. Mol. Phylogenet. Evol. 40: 61-72.

García-Varela M., Pérez-Ponce de León G., de La Torre P., Cummings M.P., Sarma S., Laclette J.P. 2000: Phylogenetic relationships of Acanthocephala based on analysis of $18 \mathrm{~S}$ ribosomal RNA gene sequences. J. Mol. Evol. 50: 532-540.

Garey J.R., Schmidt-Rhaesa A., Near T.J., Nadler S.A. 1998: The evolutionary relationships of rotifers and acanthocephalans. Hydrobiologia 387: 83-91.

Gazi M., Sultana T., Min G.S., Park Y.C., García-Varela M., NAdler S.A., PARK J.K. 2012: The complete mitochondrial genome sequence of Oncicola luehei (Acanthocephala: Archiacanthocephala) and its phylogenetic position within Syndermata. Parasitol. Int. 61: 307-316.

Gissi C., Iannelli F., Pesole G. 2008: Evolution of the mitochondrial genome of Metazoa as exemplified by comparison of congeneric species. Heredity 101: 301-320.

Huelsenbeck J.P., Ronquist F. 2001: MrBayes: Bayesian inference of phylogenetic trees. Bioinformatics 17: 754-755.

Králová-Hromadová I., Tietz D.F., Shinn A.P., Špakulová M. 2003: ITS rDNA sequences of Pomphorhynchus laevis (Zoega in Müller, 1776) and P. lucyi Williams \& Rogers, 1984 (Acanthocephala: Palaeacanthocephala). Syst. Parasitol. 56: 141-145.

Kurabayashi A., Ueshima R. 2000: Complete sequence of the mitochondrial DNA of the primitive opisthobranch gastropod Pupa strigosa: systematic implication of the genome organization. Mol. Biol. Evol. 17: 266-277.

LASEK-Nesselquist E. 2012: A mitogenomic re-evaluation of the bdelloid phylogeny and relationships among the Syndermata. PLoS ONE 7: e43554.

LAVrov D.V., LANG B.F. 2005: Poriferan mtDNA and animal phylogeny based on mitochondrial gene arrangements. Syst. Biol. 54: 651-659.

Lessinger A.C., Martins Junqueira A.C., Lemos T.A., Kemper E.L., Da Silva F.R., Vettore A.L., Arruda P., AzeredoEsPIN A.M.L. 2000: The mitochondrial genome of the primary screwworm fly Cochliomyia hominivorax (Diptera: Calliphoridae). Insect Mol. Biol. 9: 521-529.

Lowe T.M., EDDY S.R. 1997: tRNAscan-SE: a program for improved detection of transfer RNA genes in genomic sequence. Nucl. Acids Res. 25: 955-964.

Mark Welch D.B. 2005: Bayesian and maximum likelihood analyses of rotifer-acanthocephalan relationships. Hydrobiologia 546: 47-54.

Melone G., Ricci C., Segers H., Wallace R.L. 1998: Phylogenetic relationships of phylum Rotifera with emphasis on the families of Bdelloidea. Hydrobiologia 377/378: 101-107. 
Min G.S., PARK J.K. 2009: Eurotatorian paraphyly: revisiting phylogenetic relationships based on the complete mitochondrial genome sequence of Rotaria rotatoria (Bdelloidea: Rotifera: Syndermata). BMC Genomics 10: 533.

Monks S. 2001: Phylogeny of the Acanthocephala based on morphological characters. Syst. Parasitol. 48: 81-116.

NEAR T.J. 2002: Acanthocephalan phylogeny and the evolution of parasitism. Integr. Comp. Biol. 42: 668-677.

Near T.J., Garey J.R., NAdLer S.A. 1998: Phylogenetic relationships of the Acanthocephala inferred from 18S ribosomal DNA sequences. Mol. Phylogenet. Evol. 10: 287-298.

Park J.K., Sultana T., Lee S.H., Kang S., Kim H.K., Min G.S., Eom K.S., Nadler S.A. 2011: Monophyly of clade III nematodes is not supported by phylogenetic analysis of complete mitochondrial genome sequences. BMC Genomics 12: 392.

Passamaneck Y., Halanych K.M. 2006: Lophotrochozoan phylogeny assessed with LSU and SSU data: evidence of lophophorate polyphyly. Mol. Phylogenet. Evol. 40: 20-28.

Perrot-Minnot M.J. 2004: Larval morphology, genetic divergence, and contrasting levels of host manipulation between forms of Pomphorhynchus laevis (Acanthocephala). Int. J. Parasitol. 34: 45-54.

Podsiadlowski L., Braband A., Struck T.H., Von Döhren J., Bartolomaeus T. 2009: Phylogeny and mitochondrial gene order variation in Lophotrochozoa in the light of new mitogenomic data from Nemertea. BMC Genomics 10: 364.

Sснмidt G.D. 1985: Development and life cycles. In: B.B. Nickol and D.W.T. Crompton (Eds.), Biology of the Acanthocephala. Cambridge University Press, Cambridge, pp. 273-286.

Sørensen M.V., Giribet G. 2006: A modern approach to rotiferan phylogeny: combining morphological and molecular data. Mol. Phylogenet. Evol. 40: 585-608.

Sørensen M.V., Segers H., Funch P. 2005: On a new Seison Grube, 1861 from coastal waters of Kenya, with a reappraisal of the classification of the Seisonida (Rotifera). Zool. Stud. 44: 34-43.

Stach T., Braband A., Podsiadlowski L. 2010: Erosion of phylogenetic signal in tunicate mitochondrial genomes on different levels of analysis. Mol. Phylogenet. Evol. 55: 860-870.

Steinauer M.L., Nickol B.B., Broughton R., Ortí G. 2005: First sequenced mitochondrial genome from the phylum Acanthocephala (Leptorhynchoides thecatus) and its phylogenetic position within Metazoa. J. Mol. Evol. 60: 706-715.
Suga K., Welch D.B.M., Tanaka Y., Sakakura Y., Hagiwara A. 2008: Two circular chromosomes of unequal copy number make up the mitochondrial genome of the rotifer Brachionus plicatilis. Mol. Biol. Evol. 25: 1129-1137.

Tamura K., Peterson D., Peterson N., Stecher G., Nei M., KumAR S. 2011: MEGA5: molecular evolutionary genetics analysis using maximum likelihood, evolutionary distance, and maximum parsimony methods. Mol. Biol. Evol. 28: 2731-2739.

TAng S., Hyman B.C. 2007: Mitochondrial genome haplotype hypervariation within the isopod parasitic nematode Thaumamermis cosgrovei. Genetics 176: 1139-1150.

Thompson J.D., Gibson T.J., Plewniak F., Jeanmougin F., HigGINS D.G. 1997: The CLUSTAL X windows interface: flexible strategies for multiple sequence alignment aided by quality analysis tools. Nucl. Acids Res. 25: 4876-4882.

VALLĖS Y., Boore J.L. 2006: Lophotrochozoan mitochondrial genomes. Integr. Comp. Biol. 46: 544-557.

Wang W.B., Zeng B.P., Wang Z., Luo Y.S., Wang J.R. 2004: [Studies on the population ecology of Pallisentis (Neosentis) celatus in its host Monopterus albus.] J. Huazhong Agric. Univ. 23: 650-653. (In Chinese, English )

Weber M., Wey-Fabrizius Alexandra R., Podsiadlowski L., Witek A., Schill Ralph O., Sugár L., Herlyn H., Hankeln T. 2013: Phylogenetic analyses of endoparasitic Acanthocephala based on mitochondrial genomes suggests secondary loss of sense organs. Mol. Phylogenet. Evol. 66: 182-189.

Witek A., Herlyn H., Meyer A., Boell L., Bucher G., HanKELN T. 2008: EST based phylogenomics of Syndermata questions monophyly of Eurotatoria. BMC Evol. Biol. 8: 345.

Wyman S.K., JANSEN R.K., Boore J.L. 2004: Automatic annotation of organellar genomes with DOGMA. Bioinformatics 20: 3252-3255.

Zeng B.P., WANG W.B. 2007: Seasonal population dynamics of Pallisentis (Neosentis) celatus (Acanthocephala: Quadrigyridae) in the intestine of the rice-field eel Monopterus albus in China. J. Helminthol. 81: 415-420.

Zhao Q.P., Zhang S.H., Deng Z.R., Jiang M.S., Nie P. 2010: Conservation and variation in mitochondrial genomes of gastropods Oncomelania hupensis and Tricula hortensis, intermediate host snails of Schistosoma in China. Mol. Phylogenet. Evol. 57: 215-226.

Accepted 10 March 2013 